\title{
Itraconazole treatment reduces Batrachochytrium dendrobatidis prevalence and increases overwinter field survival in juvenile Cascades frogs
}

\author{
Bennett M. Hardy ${ }^{1, *}$, Karen L. Pope ${ }^{2}$, Jonah Piovia-Scott ${ }^{3}$, Richard N. Brown ${ }^{1}$, \\ Janet E. Foley ${ }^{4}$ \\ ${ }^{1}$ Department of Wildlife, Humboldt State University, Arcata, California 95521, USA \\ ${ }^{2}$ US Forest Service, Pacific Southwest Research Station, Arcata, California 95521, USA \\ ${ }^{3}$ Department of Biology, University of California, Riverside, California 92525, USA \\ ${ }^{4}$ Department of Veterinary Medicine and Epidemiology, University of California, Davis, California 95616, USA
}

\begin{abstract}
The global spread of the fungal pathogen Batrachochytrium dendrobatidis ( $B d$ ) has led to widespread extirpation of amphibian populations. During an intervention aimed at stabilizing at-risk populations, we treated wild-caught Cascades frogs Rana cascadae with the antifungal drug itraconazole. In fall 2012, we collected 60 recently metamorphosed $R$. cascadae from 1 of the 11 remnant populations in the Cascades Mountains (CA, USA). Of these, 30 randomly selected frogs were treated with itraconazole and the other 30 frogs served as experimental controls; all were released at the capture site. $B d$ prevalence was low at the time of treatment and did not differ between treated frogs and controls immediately following treatment. Following release, $B d$ prevalence gradually increased in controls but not in treated frogs, with noticeable (but still nonsignificant) differences $3 \mathrm{wk}$ after treatment (27\% [4/15] vs. $0 \%$ [0/13]) and strong differences 5 wk after treatment (67\% [8/12] vs. $13 \%$ [1/8]). We did not detect any differences in $B d$ prevalence and load between experimental controls and untreated wild frogs during this time period. In spring 2013, we recaptured 7 treated frogs but none of the experimental control frogs, suggesting that over-winter survival was higher for treated frogs. The itraconazole treatment did appear to reduce growth rates: treated frogs weighed $22 \%$ less than control frogs $3 \mathrm{wk}$ after treatment $(0.7$ vs. $0.9 \mathrm{~g})$ and were $9 \%$ shorter than control frogs $5 \mathrm{wk}$ after treatment (18.4 vs. $20.2 \mathrm{~mm})$. However, for critically small populations, increased survival of the most at-risk life stage could prevent or delay extinction. Our results show that itraconazole treatment can be effective against $B d$ infection in wild amphibians, and therefore the beneficial effects on survivorship may outweigh the detrimental effects on growth.
\end{abstract}

KEY WORDS: Rana cascadae $\cdot$ Chytridiomycosis $\cdot$ Amphibian $\cdot$ Declines

\section{INTRODUCTION}

Batrachochytrium dendrobatidis $(B d)$, a fungus that causes the disease chytridiomycosis, has been responsible for many of the dramatic declines and dieoffs of amphibians in pristine environments around the world (Lips et al. 2006, Skerratt et al. 2007, Wake \& Vredenburg 2008, Lötters et al. 2009, Olson et al.
2013). This pathogen is cold tolerant (Berger et al. 2004), which allows it to flourish on amphibian hosts occupying cool mountain environments where the most pristine aquatic habitats tend to occur (Becker \& Zamudio 2011, Knapp et al. 2011). The Cascades frog Rana cascadae is a highly aquatic, montane frog endemic to the Pacific Northwest of the USA from the Olympic Peninsula of Washington to the southern 
Cascade Range in California. At the southern extent of its range, Cascades frogs have experienced significant declines (Fellers et al. 2008) and recent evidence supports the hypothesis that chytridiomycosis was responsible for the extirpation of $R$. cascadae from dozens (if not hundreds) of sites in the southern Cascade Range in California (Pope et al. 2014). Only 11 populations of $R$. cascadae are known to remain in the region, and 6 of these are near extirpation (Pope et al. 2014). All of the remnant populations are infected with $B d$, and chytridiomycosis is considered the primary threat to population persistence (Pope et al. 2014).

Management options to reduce extinction risk due to chytridiomycosis include actions that reduce $B d$ in the environment or on hosts, or actions that increase population buffering capacity (Scheele et al. 2014). One action suggested by Scheele et al. (2014) to reduce $B d$ on hosts is to identify life stages where $B d$ threatens population viability and temporarily bring individuals at that stage into captivity to clear the infection, then return them to the wild. Here, we test the effectiveness of this approach by treating wildcaught, recently metamorphosed $R$. cascadae with the antifungal drug itraconazole and monitoring their post-release survival at the capture-site.

We selected first year frogs because we have observed extremely low overwinter survival of this year class (K. L. Pope et al. unpubl. data), and juvenile $R$. cascadae (including young of the previous year) have the highest $B d$ prevalence and infection intensity of any life stage (Piovia-Scott et al. 2011). We hypothesize that a rapid increase in $B d$ infection occurs during the cool fall period between metamorphosis and overwintering, as recently metamorphosed animals appear to be especially vulnerable to infection (Rollins-Smith et al. 2011) and are likely to be exposed to the motile, waterborne fungal zoospores since they remain closely tied to water following metamorphosis. Under this hypothesis, many first year frogs are predicted to succumb to the disease prior to snow melt the following spring. If this is true, then treatment of newly metamorphosed frogs during the fall may have high potential for positive impacts at the population level. In critically at-risk populations, treatment of juveniles with antifungal agents may increase recruitment into the more resilient older life stages.

Some effort has been devoted to developing safe treatments for $B d$-infected amphibians (Berger et al. 2010, Woodhams et al. 2011, Baitchman \& Pessier 2013). Most of this research has focused on laboratory trials of antifungal drugs and their effects on $B d$ and the infected amphibians (Nichols et al. 2000, Garner et al. 2009, Berger et al. 2010, Brannelly et al. 2012). Many antifungals have been tested, including formalin and malachite green, copper sulfate, miconazole, fluconazole, benzalconium chloride, terbinafine hydrochloride, voriconazole, and itraconazole (Berger et al. 2010, Bowerman et al. 2010, Martel et al. 2011, Baitchman \& Pessier 2013). Based on research to date, low doses of itraconazole appear to be among the safest and most effective options for treating amphibians with chytridiomycosis (Garner et al. 2009, Berger et al. 2010, Brannelly et al. 2012).

Itraconazole has been used both in veterinary and human medicine for treatment of fungal infections and works by inhibiting the synthesis of ergosterol, a primary part of fungal cell membranes (Marichal et al. 1999). Itraconazole concentrates and persists in keratinized tissues in mammals (Riviere \& Papich 2009); if this is also true for amphibians, itraconazole may be especially effective against chytridiomycosis because $B d$ lives in the keratinized epithelial tissues of amphibians (Marantelli et al. 2004). Use of itraconazole on amphibians, however, can cause sideeffects including excessive skin sloughing, lethargy, loss of appetite, mortality at high dosages, and possibly immunosuppression (Berger et al. 2010, Brannelly et al. 2012, Venesky et al. 2014). Nevertheless, it remains the most commonly used antifungal agent for treatment of amphibians infected with $B d$ (Baitchman \& Pessier 2013).

The objective of this study was to measure the efficacy of itraconazole treatment on wild juvenile Cascades frogs collected from a declining, $B d$-positive population. Our specific goals were to determine if treatment with itraconazole (1) clears $B d$ infections, (2) leads to persistent reductions in $B d$ infection after treated animals are returned to the field, (3) improves over-winter survival, and (4) causes any observable adverse effects. We hypothesized that the itraconazole treatment would reduce the prevalence and intensity of $B d$ infection and lead to higher overwinter survival in the treated group relative to untreated controls.

\section{MATERIALS AND METHODS}

\section{Frog collection and housing}

On 7 September 2012, we collected 60 newly metamorphosed frogs from a $B d$-positive population of about 150 adult Cascades frogs in Carter Meadow (401' $17^{\prime \prime} \mathrm{N}, 121^{\circ} 24^{\prime} 45^{\prime \prime} \mathrm{W}$; $1860 \mathrm{~m}$ elevation) on a 
headwater drainage of Deer Creek, Lassen National Forest, California. We have studied the population of Cascades frogs in Carter Meadow intensively since 2008 and have found extremely low over-winter survival of first year frogs (K. L. Pope et al. unpubl. data). Using dip-nets, we collected the frogs from an approximately $90 \mathrm{~m}^{2}$ area associated with 2 adjacent breeding pools in the eastern portion of the meadow. Frogs were placed in individual Ziploc bags filled with a small amount of locally collected water before being placed in portable coolers kept cool with ice packs.

Once 60 frogs were collected, we immediately transported them by car ( $350 \mathrm{~km}, 5 \mathrm{~h}$ travel time) to Humboldt State University (HSU) in Arcata, California. The frogs were housed individually in sterile 5.7 l plastic Tupperware containers arranged on metal racks in the HSU Wildlife Game Pens walk-in cold room, in which the temperature was maintained at between 10 and $13^{\circ} \mathrm{C}$. The containers were filled with $150 \mathrm{ml}$ of filtered tap water and placed at about a $20^{\circ}$ angle to allow for basking both in and out of the water. An upside-down plastic dish with a hole cut in one side was placed in the dry portion of each container to provide refuge.

\section{Treatment protocol and re-surveys}

The day after collection (Day 1), all frogs were swabbed with a sterile swab following the technique outlined by Boyle et al. (2004) to determine initial Bd zoospore intensity. We ran a sterile swab (Medical Wire and Equipment) 5 times along the left and right inner thighs, the left and right webbing of the hind feet, and the ventral surface of the abdomen. Individual frogs were then randomly assigned to treatment ( $\mathrm{n}=30$ ) or experimental control $(\mathrm{n}=30)$ groups. Frogs were kept in their original locations so that control and treatment frogs remained randomly interspersed. Each day for $4 \mathrm{~d}$, frogs in the treatment group were individually placed in a lidded $100 \times$ $20 \mathrm{~mm}$ Petri dish containing $30 \mathrm{ml}$ of a $0.01 \%$ solution of itraconazole (Sporanox, Janssen Pharmaceutica) in reverse osmosis water. Frogs in the experimental control group were treated similarly, but the Petri dishes contained $30 \mathrm{ml}$ of plain reverse osmosis water. Animals were kept in the Petri dishes for 10 min before being placed back into their individual containers. While we used the same $0.01 \%$ concentration of itraconazole as Nichols et al. (2000) and Forzán et al. (2008), we reduced the number of treatment days from 11 to 4, and doubled the soak time from 5 to $10 \mathrm{~min}$ to minimize the length of time animals were held in a captive environment. On the second day, the water in the habitats was changed and frogs were fed a mixture of pinhead crickets and flightless fruit flies. On the last day of captivity (Day 4), all frogs were treated for the fourth time and then swabbed for $B d$, weighed with a $10 \mathrm{~g}$ Pesola scale and injected with a visual implant elastomer (VIE) dye color-coded by treatment group for field recognition after release. All needles were sterilized with 95\% alcohol, flamed and allowed to air cool between individuals. On the afternoon of the fourth day, frogs were transported back to Carter Meadow and released. Two frogs in each group died during the treatment phase of the study, resulting in the release of 28 treated and 28 experimental control frogs.

We conducted a visual encounter survey $3 \mathrm{wk}$ later, on 30 September, at and around the site of release and captured all recently metamorphosed frogs encountered. Captured frogs that had not been used in the experiment were considered 'field controls' and were used to assess the possible effects of transport and captivity on $B d$ infection. In total, we captured 13 treated, 15 experimental control, and 47 field control frogs; these individuals were weighed, measured, swabbed for $B d$, and checked for a VIE mark before being released. All animals were kept in individual bags for weighing and measuring, and were swabbed by handlers wearing disposable latex gloves that were changed after each handling of individual frogs. Two weeks later ( $5 \mathrm{wk}$ post-release) an additional visual encounter survey was conducted using the same methods described above; we captured 8 treated, 12 experimental control, and 59 field control frogs.

During the spring and summer of the following year, 7 subsequent surveys (20 May, 5 June, 12 June, 10 August, 24 August, 9 September, and 19 September) of Carter Meadow were conducted to recapture any marked or unmarked individuals from the 'young-of-previous-year' age class. All captured frogs were given a survey-specific VIE mark so we could determine the number of individuals per group without double-counting animals already recaptured.

\section{PCR diagnosis}

Quantitative PCR (qPCR) was used to identify presence and intensity of $B d$ infection. These qPCR reactions followed a protocol slightly modified from Boyle et al. (2004). We evaluated the amount of $B d$ on each 
swab in terms of zoospore equivalents (ZE) using real-time, quantitative PCR (Boyle et al. 2004, Retallick et al. 2006, Hyatt et al. 2007). Each swab was placed in a vial containing $0.5 \mathrm{ml}$ of $1 \%$ TE buffer at room temperature and shaken overnight. Swabs were then removed from the buffer and discarded, and the samples were centrifuged at $13000 \times g$ for $10 \mathrm{~min}$. The supernatant was discarded and $40 \mu \mathrm{l}$ of PrepMan Ultra (Applied Biosystems) was added to the pellets. The samples were vortexed, heated at $100^{\circ} \mathrm{C}$ for $10 \mathrm{~min}$, then centrifuged at $13000 \times g$ for $2 \mathrm{~min}$. The upper $20 \mathrm{\mu l}$ of each sample was removed and diluted in $180 \mu \mathrm{l}$ molecular grade water. Diluted DNA samples were analyzed on a Step-One Plus Real-time PCR machine (Applied Biosystems); we used $2.5 \mu \mathrm{l}$ of dilute DNA with a total reaction volume of $12.5 \mu \mathrm{l}$. Samples were run singly (Kriger et al. 2006) and $B d$ standards were run on each plate. The DNA quantity found by qPCR was multiplied by 160 to account for dilutions that occurred during processing, producing an estimate of the number of $B d$ ZEs in each sample.

\section{Data analysis}

The effects of treatment with itraconazole on $B d$ prevalence, $B d$ load, frog weight, and frog length were evaluated using exact tests (for $B d$ prevalence) and $t$-tests (for $B d$ load, frog weight, and frog length). Since experimental animals were not given individual marks (a precaution aimed at minimizing the effect of marking on animals used in the study), we were not able to use repeated-measures analyses. Instead, we conducted separate analyses for each post-treatment time point and used a sequential Bonferroni correction to evaluate statistical significance (at $\alpha=0.05$ ) while accounting for experiment-wise error rate. Effects on $B d$ prevalence were evaluated using Boschloo's unconditional exact test (Boschloo
1970, Lehmann \& Romano 2008) with Bd presence/ absence and treatment/experimental control as the 2 classification factors. We used this test because sample sizes were too low for asymptotic contingency table tests (such as Pearson's $\chi^{2}$ ), and because in most cases row and column sums were not known a priori (e.g. we did not know how many of the animals would test positive for $B d$ at any given time). For animals that tested positive, effects on $B d$ load, weight, and length were evaluated using Welch's $t$-tests ( $B d$ loads were log-transformed to meet assumptions of normality). In order to evaluate the effects of transportation, captivity, and treatment on $B d$ infection, we conducted additional analyses comparing $B d$ prevalence and load in field controls and experimental controls; these analyses were restricted to the 3 and $5 \mathrm{wk}$ sampling events as field controls were not measured at other times. Finally, to assess the effect of treatment on overwinter survival, we conducted a Boschloo's unconditional exact test comparing the number of treated and experimental control animals released in September 2012 to the number of unique individuals in each treatment group recaptured during spring and summer 2013. All analyses were conducted using the statistical software R (R Development Core Team 2012).

\section{RESULTS}

$B d$ infection rates in metamorphs of $R$. cascadae were low prior to treatment with itraconazole: 5 frogs in the treatment group and 1 in the experimental control group tested positive for $B d$ prior to the start of the experiment. Immediately after treatment and prior to release in the field, 2 of the $5 B d$-positive treated frogs remained positive, albeit at decreased intensities (532 to $138 \mathrm{ZE}$; a $56 \%$ decrease, and 2863 to $1270 \mathrm{ZE}$; a $21 \%$ decrease); the $1 B d$-positive experimental control frog remained positive but also at a

Table 1. Batrachochytrium dendrobatidis $(B d)$ infection in 3 groups of Cascades frogs Rana cascadae: treated frogs were bathed in a solution containing the antifungal drug itraconazole between 7 and 11 September 2012, experimental controls were bathed in water, field controls were not subjected to any treatment. Data are prevalences (Prev. = frogs that tested positive for $B d /$ no. sampled) and number of zoospore equivalents (ZE) in positive samples (mean $\pm \mathrm{SE}$ )

\begin{tabular}{|c|c|c|c|c|c|c|c|}
\hline \multirow[t]{2}{*}{ Experimental stage } & \multirow{2}{*}{$\begin{array}{c}\text { Date } \\
(2012)\end{array}$} & \multicolumn{2}{|c|}{ Itraconazole treatment } & \multicolumn{2}{|c|}{ Experimental control } & \multicolumn{2}{|c|}{$\ldots$ Field control } \\
\hline & & Prev. & ZE & Prev. & ZE & Prev. & ZE \\
\hline Capture & 7 Sep & $5 / 30$ & $849 \pm 505$ & $1 / 30$ & 1688 & - & \\
\hline Release & 11 Sep & $3 / 28$ & $494 \pm 389$ & $1 / 28$ & 419 & - & \\
\hline 3 wk post-treatment & $30 \mathrm{Sep}$ & $0 / 13$ & NA & $4 / 15$ & $92 \pm 52$ & $12 / 46$ & $1305 \pm 933$ \\
\hline $5 \mathrm{wk}$ post-treatment & 13 Oct & $1 / 8$ & 1952 & $8 / 12$ & $4076 \pm 1521$ & $42 / 59$ & $4959 \pm 1264$ \\
\hline
\end{tabular}



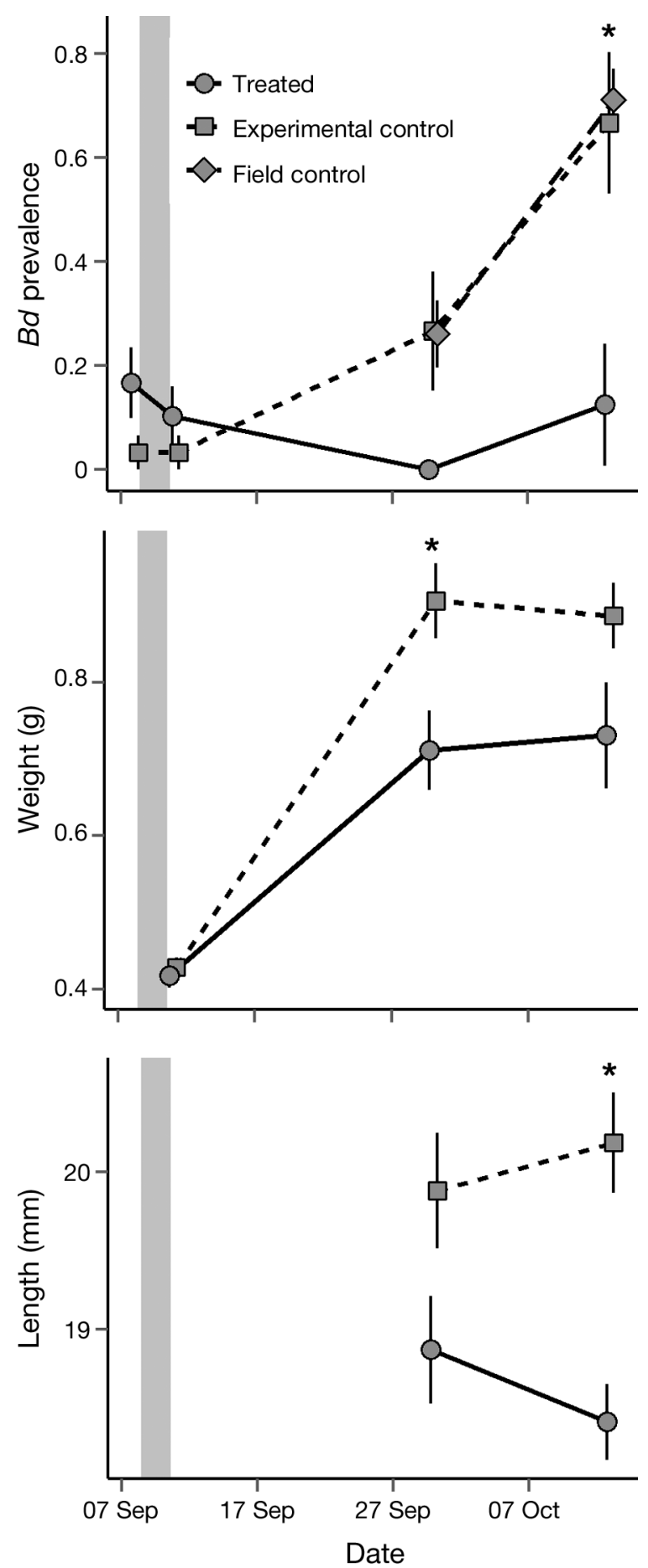

Fig. 1. Effects of itraconazole treatment on Rana cascadae metamorphs: (a) Batrachochytrium dendrobatidis (Bd) prevalence, (b) weight, and (c) length. Asterisks ( ${ }^{*}$ ) indicate significant differences between treated animals and experimental controls (see 'Materials and methods: Data analysis'). Means and SE are shown for length and weight; SE for prevalence are based on $n$ independent draws from a Bernoulli distribution and calculated as the square root of $p(1-p) / n$, where $p$ is the proportion $B d$-positive and $n$ is the number of frogs sampled. Grey bars: treatment period decreased intensity (1688 to $419 \mathrm{ZE}_{\text {; a }} 75 \%$ decrease). There was no indication that $B d$ prevalence differed between treated and experimental control animals on the last day of treatment (Boschloo's exact test, $\mathrm{p}=0.3$; Table 1, Fig. 1a). However, 3 wk after treatment there was a marginally significant trend for reduced prevalence in treated frogs (Boschloo's exact test, $\mathrm{p}=0.06) ; 5 \mathrm{wk}$ after treatment, treated frogs clearly showed a reduced $B d$ prevalence compared to experimental controls (Boschloo's exact test, $\mathrm{p}=0.015$ ), with $67 \%$ of the experimental control animals testing positive compared to $13 \%$ of treated animals. We were not able to include treated animals in analyses of $B d$ load due to the paucity of $B d$-positive animals.

We found no evidence for differences in $B d$ infection between experimental controls and field controls (Table 1): 3 wk after treatment, we did not detect differences in $B d$ prevalence (Boschloo's exact test, $\mathrm{p}=$ $0.8)$ or $B d$ load $\left(t_{11.1}=1.3, p=0.2\right)$; the same qualitative results were obtained $5 \mathrm{wk}$ after treatment $(B d$ prevalence: Boschloo's exact test, $\mathrm{p}=0.7$; $B d$ load, $t_{18.5}=0.4, \mathrm{p}=0.7$ ).

There was no indication of differences in weight between treated and experimental control animals on the last day of treatment $\left(t_{50.5}=0.5, \mathrm{p}=0.6\right.$; Fig. 1b). However, frogs that were treated with itraconazole weighed $22 \%$ less than experimental controls 3 wk after treatments were applied (0.7 vs. $0.9 \mathrm{~g}$; $t_{25.5}=2.7, \mathrm{p}=0.011$ ); this difference appeared to persist $5 \mathrm{wk}$ after treatment, although the difference was only marginally significant $\left(0.7\right.$ vs. $0.9 g_{;} t_{12.3}=1.9$, $\mathrm{p}=0.08)$. There was a marginally significant tendency for treated frogs to be shorter in length than experimental controls $3 \mathrm{wk}$ after treatment (18.9 vs. $19.9 \mathrm{~mm} ; t_{26.0}=2, \mathrm{p}=0.054$; Fig. $\left.1 \mathrm{c}\right)$; this difference was significant $5 \mathrm{wk}$ after treatment (18.4 vs. $20.2 \mathrm{~mm} ; t_{18.0}=4.4, \mathrm{p}=0.0003$ ).

A greater proportion of treated frogs ( 7 out of 28 ) than experimental controls (0 out of 28) were recaptured in the 7 surveys conducted during the spring and summer of 2013 (Boschloo's exact test, $\mathrm{p}=0.01$ ) and only 3 field controls were found. During these spring surveys, 1 of the 7 treated frogs tested positive for $B d$ and none of the 3 field controls tested positive. We recaptured 2 of the survivors from the treated group in both May and late summer of 2013. Both frogs had increased in size from $<2 \mathrm{~g}$ in May to $3.0 \mathrm{~g}$ on 24 August and $5.5 \mathrm{~g}$ on 9 September, and increased in length from 22 to 30.5 and $35.5 \mathrm{~mm}$, respectively. One additional treated frog was recaptured on 30 April 2014 and weighed $3.0 \mathrm{~g}$ and was $31.6 \mathrm{~mm}$ long. 


\section{DISCUSSION}

This study found evidence for decreased prevalence of $B d$ in newly metamorphosed frogs treated with itraconazole and then released back into the wild. The difference in $B d$ prevalence between treated frogs and experimental controls was not apparent immediately following treatment (likely due to low prevalence across both treatment groups at that time), but appeared 5 wk after treatment and release. While several studies have found that itraconazole successfully reduces infection loads in a controlled laboratory environment (Garner et al. 2009, Berger et al. 2010, Brannelly et al. 2012), this study has shown that the effects of the treatment can be sustained for at least $5 \mathrm{wk}$ after release back into a $B d$-contaminated, natural environment. In addition, $25 \%$ of the treated frogs survived the winter while survival could not be confirmed for any of the untreated, experimental control frogs. Therefore, treatment of wild, newly metamorphosed frogs with itraconazole may be a useful tool for increasing survival through a highly vulnerable life stage.

Why was the effect of treatment on $B d$ prevalence not apparent until $5 \mathrm{wk}$ after treatment? We suggest that our failure to detect a difference between treated frogs and controls on the last day of treatment was due to the fact that so few animals had detectable $B d$ infections - the control group only had 1 animal with a detectable infection at the time of treatment, so it would be challenging to find evidence for lower rates of infection in treated animals. More intriguing is the development of higher rates of infection in control frogs, but not treated frogs, over the following 3 to $5 \mathrm{wk}$. The development of high prevalence in experimental control frogs is consistent with the hypothesis laid out in the introductionrapid development of infections in newly metamorphosed frogs in late summer and early fall - and mirrors the prevalence of infection in non-experimental field controls. Treated frogs may have maintained low rates of infection during the same period for a number of reasons. First, itraconazole may have persisted in the skin throughout the 2012 sampling period, continuing to prevent infection for weeks after treatment. Itraconazole is known to persist in keratinized skin of mammals for several weeks (Riviere \& Papich 2009), however, its residence time in the skin of amphibians may be lower, as the keratinized stratum corneum is only 1 or 2 cells thick and turns over frequently (Duellman \& Trueb 1994). While Cashins et al. (2013) found no evidence for reduced rates of infection in Litoria booroolongensis exposed to $B d 80 \mathrm{~d}$ after treatment with itraconazole, shorter time frames similar to our 21 and $35 \mathrm{~d}$ periods have not been tested. Even if itraconazole did not persist in the skin for weeks after treatment, it may have persisted long enough to allow for the emergence of other factors to suppress $B d$ infection. For example, treated frogs may have developed enhanced immunity to $B d$ during the period in which they were exposed to $B d$ but were protected by the antifungal agent, allowing for persistent reductions in infection rates (McMahon et al. 2014). However, itraconazole may have had immunosuppressive effects on treated frogs, which could ultimately limit its effectiveness (Venesky et al. 2014). Nonetheless, one clear implication of our results is that even if itraconazole does not persist in amphibian skin, when treatment occurs at a critical time period it may keep animals from reaching critical loads of $B d$ (Vredenburg et al. 2010) and allow them to survive through vulnerable life stages.

Treated animals in our study were smaller than their untreated counterparts 3 and 5 wk after treatment and release. This finding of reduced growth of itraconazole-treated frogs was also observed in mountain yellow-legged frogs Rana muscosa (Woodhams et al. 2012) and seems to be an adverse effect of this chemotherapeutic treatment (Garner et al. 2009, Brannelly et al. 2012). The size of recently metamorphosed frogs has been positively correlated with survival rates (Semlitsch et al. 1988, Altwegg \& Reyer 2003) and may be especially important for animals living in habitats constrained by short growing seasons such as those at high altitudes (Metcalfe et al. 2002). Cascades frogs at the Carter Meadow study site spend about 5 or 6 mo under snow and ice during the winter and early spring. The winter of $2012 / 2013$, however, was shorter than usual with $88 \%$ of normal snowpack (California Data Exchange Center 2014). The short winter season may have facilitated the survival of small, treated frogs. Thus, while the itraconazole treatment increased apparent winter survival in $2012 / 2013$, reductions in growth rate could outweigh any benefits arising from treatment in more severe winters, when survival may be more tightly linked to body size.

Our study provides some insight into how itraconazole treatment protocols could be refined for use on post-metamorphic frogs released into $B d$ positive natural habitats. While we used the same $0.01 \%$ concentration of itraconazole as Nichols et al. (2000) and Forzán et al. (2008), we reduced the number of treatment days (from 11 to 4 ) and dou- 
bled the soak time (from 5 to $10 \mathrm{~min}$ ) in order to minimize the length of time frogs were in a captive environment. Unfortunately, this treatment caused significant reductions in growth and did not result in complete clearance of existing $B d$ infections in treated animals. It may be possible to achieve complete clearance of $B d$ infection with fewer negative effects on recently metamorphosed Cascades frogs by using a lower concentration of itraconazole administered for a greater number of days. For example, Brannelly et al. (2012) found that the administration of a $0.0025 \%$ itraconazole solution

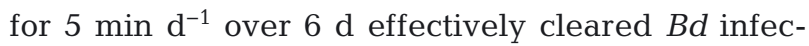
tions in the Coastal Plain toad Incilius nebulifer while minimizing harmful side effects. While further research is required to determine optimal treatment protocols for recently metamorphosed $R$. cascadae, the use of a lower itraconazole concentration $(0.0025 \%$ rather than $0.01 \%)$ is consistent with the recommendations of Baitchman \& Pessier (2013) for sensitive species and low-intensity infections, and it seems likely that a treatment protocol similar to the one highlighted by Brannelly et al. (2012) might be effective. While our research suggests that itraconazole can be an effective treatment for $B d$ infection in recently metamorphosed $R$. cascadae, it is worth noting that other treatment modalities may be more appropriate for other life stages and in other species (Baitchman \& Pessier 2013). Furthermore, the potential immunosuppressive effects of itraconazole (Venesky et al. 2014) suggest that investigations of other antifungal agents (e.g. terbinafine, voriconazole) may be worthwhile.

Our study suggests that the positive effects of itraconazole treatment outweigh the negative effects for wild juvenile frogs known to have a low chance of survival due to chytridiomycosis. This treatment could be used on juvenile frogs in critically at-risk populations to increase recruitment into more resilient older life stages, and may stave off extirpation. In addition, itraconazole treatment could be used to reduce $B d$ prevalence in source populations prior to reintroduction. For example, a plan is being developed to reintroduce Cascades frogs to Lassen Volcanic National Park; treatment with itraconazole prior to release may increase the chances of success. While our study has shown that itraconazole treatment has a prolonged effect of $B d$ reduction when in a natural $B d$-positive environment (at least $5 \mathrm{wk}$ ), further research is required to determine the mechanism for this effect and the length of treatment efficacy in additional species and environments.
Acknowledgements. Thank you to the HSU Wildlife Game Pens staff including Dr. Pia Gabriel for facilitating access to the facility; field volunteers Amy Patten, Natalie McNear, Tim Girod, Michael Sun, Sherilyn Munger, and Brooke Berger, as well as Carrie del Signore from the California Department of Fish and Wildlife; Anthony Baker from the HSU Biology Core Facility for providing laboratory supplies; Marina DeLeon of UC Davis for $\mathrm{qPCR}_{\text {; }}$ Monty Larson, Melanie McFarland, and Ryan Foote for support; and Dr. Barbara Clucas, Dr. Timothy Bean, and Dr. Daniel Barton of HSU, Dr. Bret Harvey of the USFS, and 2 anonymous reviewers for helpful comments on earlier versions. Funding was provided by the United States Forest Service, Pacific Southwest Research Station Research Emphasis Grant and a grant from the United States Fish and Wildlife Service Environmental Contaminants Program. All research was conducted under Humboldt State IACUC 1213W6-4 and California Department of Fish and Wildlife Scientific Collecting Permit SC-3905.

\section{LITERATURE CITED}

Altwegg R, Reyer HU (2003) Patterns of natural selection on size at metamorphosis in water frogs. Evolution 57: 872-882

Baitchman EJ, Pessier AP (2013) Pathogenesis, diagnosis, and treatment of amphibian chytridiomycosis. Vet Clin North Am Exot Anim Pract 16:669-685

> Becker CG, Zamudio KR (2011) Tropical amphibian populations experience higher disease risk in natural habitats. Proc Natl Acad Sci USA 108:9893-9898

> Berger L, Speare R, Hines HB, Marantelli G and others (2004) Effect of season and temperature on mortality of amphibians due to chytridiomycosis. Aust Vet J 82: 434-439

Berger L, Speare R, Pessier A, Voyles J, Skerratt LF (2010) Treatment of chytridiomycosis requires urgent clinical trials. Dis Aquat Org 92:165-174

> Boschloo RD (1970) Raised conditional level of significance for the $2 \times 2$-table when testing the equality of two probabilities. Stat Neerl 24:1-35

> Bowerman J, Rombough C, Weinstock SR, Padgett-Flohr GE (2010) Terbinafine hydrochloride in ethanol effectively clears Batrachochytrium dendrobatidis in amphibians. J Herpetol Med Surg 20:24-28

> Boyle DG, Boyle DB, Olsen V, Morgan JAT, Hyatt AD (2004) Rapid quantitative detection of chytridiomycosis (Batrachochytrium dendrobatidis) in amphibian samples using real-time Taqman PCR assay. Dis Aquat Org 60:141-148

- Brannelly LA, Richards-Zawacki CL, Pessier AP (2012) Clinical trials with itraconazole as a treatment for chytrid fungal infections in amphibians. Dis Aquat Org 101:95-104

California Data Exchange Center (2014) Department of Water Resources, Sacramento, CA. www.cdec.water.ca. gov (accessed 21 Jan 2014)

Cashins SD, Grogan LF, McFadden M, Hunter D, Harlow PS, Berger L, Skerratt LF (2013) Prior infection does not improve survival against the amphibian disease chytridiomycosis. PLoS ONE 8:e56747

Duellman WE, Trueb L (1994) Biology of amphibians. Johns Hopkins University Press, Baltimore, MD

Fellers GM, Pope KL, Stead JE, Koo MS, Welsh HH (2008) Turning population trend monitoring into active conservation: Can we save the Cascades frog (Rana cascadae) 
in the Lassen Region of California? Herpetol Conserv Biol 3:28-39

Forzán MJ, Gunn H, Scott P (2008) Chytridiomycosis in an aquarium collection of frogs: diagnosis, treatment, and control. J Zoo Wildl Med 39:406-411

Garner TWJ, Garcia G, Carroll B, Fisher MC (2009) Using itraconazole to clear Batrachochytrium dendrobatidis infection, and subsequent depigmentation of Alytes muletensis tadpoles. Dis Aquat Org 83:257-260

> Hyatt AD, Boyle DG, Olsen V, Boyle DB and others (2007) Diagnostic assays and sampling protocols for the detection of Batrachochytrium dendrobatidis. Dis Aquat Org 73:175-192

Knapp RA, Briggs CJ, Smith TC, Maurer JR (2011) Nowhere to hide: impact of a temperature sensitive amphibian pathogen along an elevation gradient in the temperate zone. Ecosphere 2:art93

Kriger KM, Hines HB, Hyatt AD, Boyle DG, Hero JM (2006) Techniques for detecting chytridiomycosis in wild frogs: comparing histology with real-time Taqman PCR. Dis Aquat Org 71:141-148

Lehmann EL, Romano JP (2008) Testing statistical hypotheses, 3rd edn. Springer, New York, NY

Lips KR, Brem F, Brenes R, Reeve JD and others (2006) Emerging infectious disease and the loss of biodiversity in a Neotropical amphibian community. Proc Natl Acad Sci USA 103:3165-3170

Lötters S, Kielgast J, Bielby J, Schmidtlein S and others (2009) The link between rapid enigmatic amphibian decline and the globally emerging chytrid fungus. EcoHealth 6:358-372

Marantelli G, Berger L, Speare L, Keegan L (2004) Distribution of Batrachochytrium dendrobatidis and keratin during tadpole development. Pac Conserv Biol 10: 173-179

Marichal P, Gorrens J, Laurijssens L, Vermuyten K and others (1999) Accumulation of 3-ketosteroids induced by itraconazole in azole-resistant clinical Candida albicans isolates. Antimicrob Agents Chemother 43:2663-2670

- Martel A, Van Rooij P, Vercauteren G, Baert K and others (2011) Developing a safe antifungal treatment protocol to eliminate Batrachochytrium dendrobatidis from amphibians. Med Mycol 49:143-149

McMahon TA, Sears BF, Venesky MD, Bessler SM and others (2014) Amphibians acquire resistance to live and dead fungus overcoming fungal immunosuppression. Nature 511:224-227

Metcalfe NB, Bull CD, Mangel M (2002) Seasonal variation in catch-up growth reveals state-dependent somatic allocations in salmon. Evol Ecol Res 4:871-881

Nichols DK, Lamirande EW, Pessier AP, Longcore JE (2000) Experimental transmission and treatment of cutaneous chytridiomycosis in poison dart frogs (Dendrobates auratus and Dendrobates tinctorius). In: Proceedings of the American Association of Zoo Veterinarians and International Association for Aquatic Animal Medicine Joint Conference, New Orleans, LA, 17-21 Sep 2000, p 42-44

Editorial responsibility: Lee Skerratt,

Townsville, Queensland, Australia
Olson DH, Aanensen DM, Ronnenberg KL, Powell CI and others (2013) Mapping the global emergence of Batrachochytrium dendrobatidis, the amphibian chytrid fungus. PLoS ONE 8:e56802

$>$ Piovia-Scott J, Pope KL, Lawler SP, Cole EM, Foley JE (2011) Factors related to the distribution and prevalence of the fungal pathogen Batrachochytrium dendrobatidis in Rana cascadae and other amphibians in the Klamath Mountains. Biol Conserv 144:2913-2921

Pope KL, Brown C, Hayes MJ, Green G, Macfarlane D (2014) Cascades frog conservation assessment. USDA Forest Service Gen Tech Rep No. PSW-GTR-244. Pacific Southwest Research Station, Arcata, CA. www.fs.fed.us/psw/ publications/documents/psw_gtr244/psw_gtr244.pdf

Retallick RWR, Miera V, Richards KL, Field KJ, Collins JP (2006) A non-lethal technique for detecting the chytrid fungus Batrachochytrium dendrobatidis on tadpoles. Dis Aquat Org 72:77-85

R Development Core Team (2012) R: a language and environment for statistical computing. R Foundation for Statistical Computing, Vienna. www.r-project.org

Riviere JE, Papich MG (2009) Veterinary pharmacology and therapeutics, 9th edn. Wiley-Blackwell, Ames, IA

Rollins-Smith LA, Ramsey JP, Pask JD, Reinert LK, Woodhams DC (2011) Amphibian immune defenses against chytridiomycosis: impacts of changing environments. Integr Comp Biol 51:552-562

Scheele BC, Hunter DA, Grogan L, Berger L and others (2014) Interventions for reducing extinction risk in chytridiomycosis-threatened amphibians. Conserv Biol 28:1195-1205

Semlitsch RD, Scott DE, Pechmann JH (1988) Time and size at metamorphosis related to adult fitness in Ambystoma talpoideum. Ecology 69:184-192

> Skerratt LF, Berger L, Speare R, Cashins S and others (2007) Spread of chytridiomycosis has caused the rapid global decline and extinction of frogs. EcoHealth 4:125-134

$>$ Venesky MD, Raffel TR, McMahon TA, Rohr JR (2014) Confronting inconsistencies in the amphibian-chytridiomycosis system: implications for disease management. Biol Rev Camb Philos Soc 89:477-483

> Vredenburg VT, Knapp RA, Tunstall TS, Briggs CJ (2010) Dynamics of an emerging disease drive large-scale amphibian population extinctions. Proc Natl Acad Sci USA 107:9689-9694

> Wake DB, Vredenburg VT (2008) Are we in the midst of the sixth mass extinction? A view from the world of amphibians. Proc Natl Acad Sci USA 105:11466-11473

Woodhams DC, Bosch J, Briggs CJ, Cashins S and others (2011) Mitigating amphibian disease: strategies to maintain wild populations and control chytridiomycosis. Front Zool 8:8

> Woodhams DC, Geiger CC, Reinert LK, Rollins-Smith LA and others (2012) Treatment of amphibians infected with chytrid fungus: learning from failed trials with itraconazole, antimicrobial peptides, bacteria, and heat therapy. Dis Aquat Org 98:11-25

Submitted: March 14, 2014; Accepted: October 7, 2014 Proofs received from author(s): December 10, 2014 